\title{
ANALISIS USABILITY TESTING PADA APLIKASI TRANSPORTASI ONLINE UNTUK MENGUKUR KEPUASAN PENGGUNA
}

\author{
Nanda Arsyia Murti \\ Jurusan Sistem Informasi Bisnis Fakultas Manajemen Sistem Informasi Universitas Gunadarma \\ Jln. Kenari nomor 13 Jakarta Pusat, 10430 \\ nandaarsyiamurti@yahoo.com
}

\begin{abstract}
Abstrak - Aplikasi transportasi online di Indonesia semakin menunjukkan perkembangan yang signifikan hal ini ditunjukkan oleh beberapa perusahaan yang memberikan pelayanan dalam aplikasi transportasi online seperti A, B dan C, namun masih ditemukan masalah-masalah dalam penggunaannya di wilayah Jabodetabek. Penelitian ini bertujuan untuk menganalisis tingkat usability testing dan menganalisis perbedaan usability testing pada aplikasi transportasi online A, B dan C untuk mengukur kepuasan pengguna di wilayah Jabodetabek. Penentuan sampel dilakukan dengan teknik cluster sampling dengan jumlah sebanyak 96 pengguna. Data dikumpulkan melalui penyebaran kuesioner kemudian dianalisis secara statistik deskriptif dan Independent-Sample T-Test dengan program SPSS versi 23. Hasil analisis data diperoleh bahwa aplikasi transportasi online A dan B memiliki tingkat kemudahaan, efisiensi, mudah diingat, keamanan dan kepuasan pengguna yang tinggi. Sementara itu aplikasi transportasi online $\mathrm{C}$ memiliki tingkat kemudahan, efisiensi dan mudah diingat yang tinggi, namun memiliki tingkat keamanan dan kepuasan pengguna dengan tingkat sedang. Tidak terdapat perbedaan usability testing pada aplikasi tranportasi online A dengan B untuk mengukur tingkat kepuasan pengguna di wilayah Jabobetabek, namun aplikasi transportasi online A dan B memiliki perbedaan usability testing secara singnifikan untuk mengukur tingkat kepuasan pengguna di wilayah Jabobetabek.
\end{abstract}

Kata kunci : Usability Testing, Transportasi Online, Cluster Sampling

\section{Pendahuluan}

Mobilitas masyarakat Indonesia yang sangat tinggi, terutama di wilayah Jabodetabek membuat perusahaan transportasi online beradu menawarkan jenis layanan jasa yang sama sehingga terjadi persaingan yang kompetitif antar transportasi online.

Transportasi online A memberikan pelayanan di bidang jasa antar dengan kendaraan bermotor, jasa antara dengan mobil, pembelian makanan, pengiriman paket, kesehatan, pembelian pulsa, jasa pembersihan rumah maupun jasa lainnya. Aplikasi transportasi online A yang belum berhasil menciptakan fintech untuk metode pembayaran secara elektronik sendiri, transportasi online A masih bekerja sama dengan perusahaan fintech pertama dan terkemuka di
Indonesia yang memberi kemudahan bagi penggunanya melakukan transaksi.

Aplikasi transportasi online B juga melakukan ekspansi dalam memudahkan pelanggannya dalam hal pembayaran. Tranportasi online B menyediakan metode pembayaran secara elektronik (financial technology) yang membuat penggunanya dimudahkan dalam melakukan transaksi tanpa menggunakan uang tunai saat ini banyak transaksi-transaksi dilakukan pelanggan dengan menggunakan fintech dari transportasi online B. Aplikasi ini juga melakukan kerjasama dengan salah satu perusahaan taksi di Jakarta.

Pendatang baru, transportasi online $\mathrm{C}$ masih sedikit memberikan pelayanan, yaitu hanya sebatas pelayanan jasa antar dengan kendaraan bermotor dan mobil kemudian jasa antar paket saja. Aplikasi transportasi online $\mathrm{C}$ justru telah memiliki fasilitas pembayaran secara elektronik sendiri yang memberi kemudahan dalam melakukan transaksi pembayaran, 
namun saat ini pembayaran hanya digunakan dalam transaksi di aplikasi tersebut saja.

Masing-masing penyedia layanan tranportasi online saling berlomba dalam mengembangkan aplikasi yang diciptakan dengan melakukan berbagai inovasi yang ditawarkan dalam pelayanannya namun tidak serta merta aplikasi yang dikembangkan menunjukkan kinerja yang maksimal sesuai dengan tuntutan pelanggan berbagai masalah kadang terjadi dalam penggunaan aplikasi transportasi online tersebut Berikut gambar 1 kerangka konseptual dalam penelitian ini.

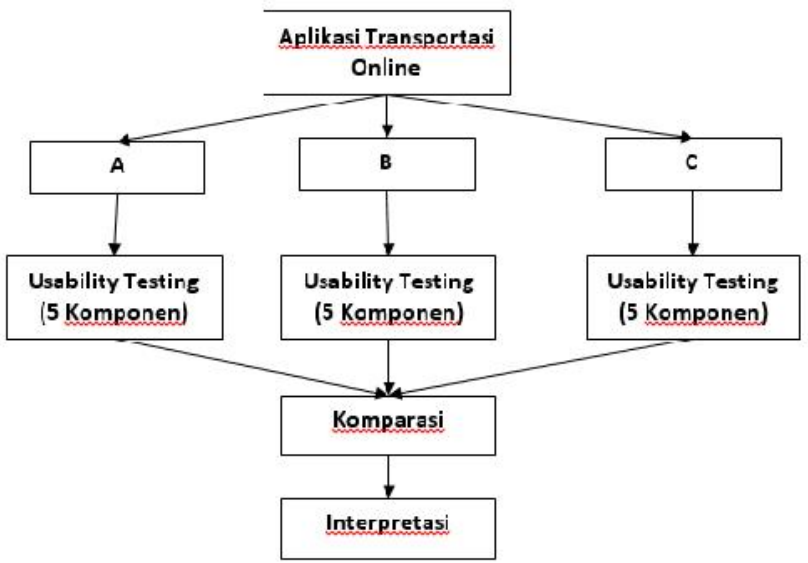

Gambar 1. Kerangka Konseptual

Permasalahan yang ditemukan pada pengguna (user) aplikasi transportasi online adalah sebagai berikut Akurasi GPS masih sering tidak akurat, beberapa pengguna juga mengeluhkan tidak dapat memasukkan alamat yang tepat sehingga harus mengisi alamat secara manual, Aplikasi sering tidak merespon karena server error, Terjadi kesulitan dalam proses login ke aplikasi.

Masalah tersebut dijumpai oleh beberapa pengguna aplikasi transportasi online sebagai upaya dalam menilai kredibilitas aplikasi transportasi online dalam meningkatkan loyalitas penggunanya maka setiap aplikasi harus memiliki tingkat usability yang baik. Untuk itu perlu dilakukan usability testing antar aplikasi online tersebut. Komponen dari usability tasting meliputi: kemudahan, efisiensi, mudah diingat, kesalahan/keamanan, dan kepuasan.

Berbagai penelitian lain telah melakukan kajian mengenai tingkat usability testing pada aplikasi transportasi online tetapi dalam penelitian ini mencoba melakukan komparasi dari komponen usability seperti tingkat kemudahan, efisiensi, mudah diingat, kesalahan, kepuasan penggunaan antara aplikasi tranportasi online A, aplikasi tranportasi online B dan aplikasi tranportasi online $\mathrm{C}$ di wilayah Jabodetabek
Tujuan penelitian untuk menganalisis usability testing pada aplikasi transportasi online $\mathrm{A}, \mathrm{B}$ dan $\mathrm{C}$ di wilayah Jabodetabek dan untuk mengetahui perbedaan usability testing pada aplikasi transportasi online A, B dan C di wilayah Jabodetabek supaya bermanfaat bagi pengguna untuk merekomendasikan kepada pengguna yang lain sesuai dengan pengalaman yang dirasakan dalam penggunaan aplikasi transportasi online pilihan.

\section{Metodologi Penelitian}

Metodelogi penelitian ini yaitu pengukuran tingkat usability testing yang meliputi lima komponen seperti tingkat kemudahan, efisiensi, mudah diingat, kesalahan, kepuasan pada penggunaan tiga aplikasi tranportasi online yaitu A, B dan C. Langkah-langkah penelitian disajikan pada gambar 2.

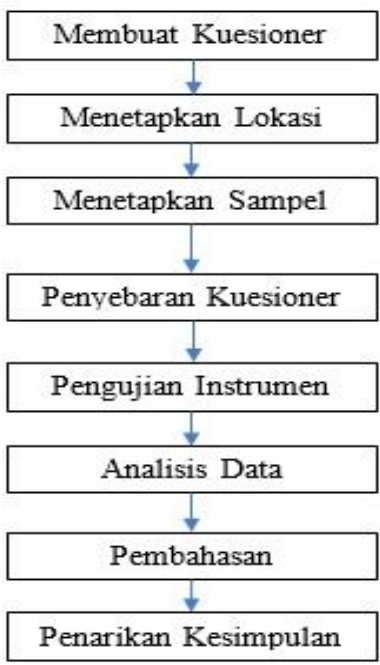

Gambar 2. Langkah-Langkah Penelitian

Melalui lima komponen usability testing dikembangkan pernyataan-pernyataan dalam kuesioner yang mencakup tingkat kemudahan, efisensi, mudah diingat, kesalahan dan kepuasan pengguna

Penelitian ini menetapkan lokasi penelitian di Jabodetabek, yang mana pengguna (user) aplikasi transportasi online A, B dan $\mathrm{C}$ yang berlokasi di Jabodetabel sebagai unit analisis yang digunakan dalam penelitian.

Populasi dalam penelitian ini yaitu para pengguna aktif aplikasi online $\mathrm{A}, \mathrm{B}$ dan $\mathrm{C}$ yang mana dalam hal ini jumlahnya tidak diketahui secara pasti Untuk itu, dalam menentukan jumlah sampel digunakan rumus dengan demikian diperoleh jumlah sampel minimal yaitu 96 , untuk itu dalam penelitian ini ditetapkan sampel sebanyak 96 pengguna dalam setiap aplikasi transportasi online. teknik pengambilan sampel ditentukan dengan metode probability sampling yaitu teknik cluster sampling dengan demikian, jumlah sampel yang digunakan sebanyak 96 dalam tiga cluster 
(pengguna aplikasi transportasi online A, pengguna aplikasi transportasi online B dan pengguna aplikasi transportasi online C).

Kuesioner dalam penelitian ini dibuat berdasarkan indikator dari masing-masing komponen dari usability testing. Teknik pengukuran kuesioner dalam penelitian ini diukur dengan skala likert. Pada penelitian ini tingkat penilaiannya dengan skala 1 (sangat tidak setuju) - 4 (sangat setuju). Kuesioner disebarkan melalui bantuan google form, dari keseluruhan responden yang ikut berpartisipasi dalam pengisian kuesioner, diambil masing-masing 32 sampel dari pengguna aplikasi A, B atupun $\mathrm{C}$.

Pengujian instrument dalam penelitian ini dilakukan dengan uji validitas dan uji reliabilitas. Uji validitas dalam penelitian ini memiliki hasil uji yang menunjukkan bahwa nilai Sig. correlation $<\alpha(5 \%)$ yang artinya bahwa semua variabel yang digunakan dalam instrumen penelitian adalah valid. Dalam penelitian ini digunakan model korelasi Product Moment Pearson dengan bantuan program SPSS versi 23. Pengujian reliabilitas terhadap semua item atau pernyataan yang dipergunakan pada penelitian ini akan menggunakan formula Cronbach Alpha yang dilakukan dengan program SPSS versi 23, dikatakan reliabel jika nilai Cronbach Alpha $\geq$ 0,6 .

Analisis data dilakukan dengan mendeskripsikan data terlebih dahulu melalui analisis deskriptif. Tujuan dari analisis deskriptif adalah untuk mendapatkan data yang menggambarkan topik yang menarik. tahap selanjutnya dilakukan Uji Beda T-Test, yang mana pengujian ini digunakan untuk mengetahui signifikansi rata-rata antara sampel yang saling independen, yaitu melalui Independent - Sample T-Test, Pengujian ini menunjukkan apakah ada atau tidak ada perbedaan ratarata yang signifikan dalam variabel dependen antara dua kelompok, analisis varians (ANOVA) membantu untuk menguji perbedaan rata-rata yang signifikan antara lebih dari dua kelompok pada yang diskalakan dalam interval atau rasio.

Pembahasan didasarkan atas hasil analisis data melalui analisis deskriptif dan uji beda. Pembahasan hasil analisis deskripsi berkaitan dengan bagaimana menguraikan maksud dari nilai rata-rata dari setiap indikator dari komponen usability testing. Semakin tinggi nilai rata-rata yang dihasilkan maka akan semakin baik tingkat usability testing. Pembahasan hasil analisis selanjutnya didasarkan atas hasil analisis uji beda. Dalam hal ini akan diuraikan mengenai perbandingan tingkat usability testing dari masingmasing aplikasi

\section{HASIL DAN PEMBAHASAN}

Data penelitian dikumpulkan melalui instrument kuesioner, sehingga perlu dilakukan pengujian mengenai kualitas data penelitian

Uji validitas kuesioner dilakukan dengan uji korelasi product moment Pearson dengan hasil sebagai berikut.

\begin{tabular}{ccccc}
\hline Komponen & No & $\mathrm{R}_{\text {hitumg }}$ & $\mathrm{r}_{\text {tabel }}$ & Keterangan \\
\hline \multirow{3}{*}{ Kemudahan } & 1 & 0,804 & 0,2006 & Valid \\
& 2 & 0,883 & 0,2006 & Valid \\
Efisiensi & 3 & 0,542 & 0,2006 & Valid \\
& 4 & 0,745 & 0,2006 & Valid \\
& 5 & 0,789 & 0,2006 & Valid \\
& 6 & 0,836 & 0,2006 & Valid \\
Mudah diingat & 7 & 0,678 & 0,2006 & Valid \\
& 9 & 0,873 & 0,2006 & Valid \\
& 10 & 0,941 & 0,2006 & Valid \\
Kesalahan & 11 & 0,815 & 0,2006 & Valid \\
& 12 & 0,876 & 0,2006 & Valid \\
& 13 & 0,835 & 0,2006 & Valid \\
& 14 & 0,935 & 0,2006 & Valid \\
Kepuasan & 15 & 0,927 & 0,2006 & Valid \\
& 16 & 0,834 & 0,2006 & Valid \\
\hline
\end{tabular}

Gambar 3. Hasil uji coba validitas

Diketahui bahwa nilai koefisien korelasi (r hitung) dalam setiap butir pernyataan telah lebih dari 0,2006. Hal ini menunjukkan bahwa setiap butir pernyataan telah dinyatakan valid, sehingga memenuhi sebagai instrument penelitian

Uji reliabilitas dilakukan dengan rumus Cronbach Alpha dengan hasil sebagai berikut.

\begin{tabular}{|c|c|c|c|}
\hline Komponen & Crootbach Alloha & Ketentuan & Keterangan \\
\hline Kemudadhan & 0.628 & & Reliabol \\
\hline Efisisensi & 0,675 & & Reliabel \\
\hline Mudald diingat & 0.44 & $>0,60$ & Reliabel \\
\hline Kesaldhan & 0.865 & & Reliabel \\
\hline Kepulassan & 0,878 & & Reliablel \\
\hline
\end{tabular}

Gambar 4. Hasil uji coba realibitas

nilai Cronbach alpha dari setiap komponen dalam usability testing telah lebih dari 0,6 . Hal ini menunjukkan bahwa kuesioner penelitian telah dinyatakan reliabel 
Jumlah sampel yang digunakan dalam penelitian ini yaitu sebanyak 96 responden yang mana dalam setiap cluster digunakan 32 responden. Deskripsi dari responden penelitian diuraikan sebagai berikut.

\begin{tabular}{|c|c|c|}
\hline & Jumlah & Persentase \\
\hline Aplikasi Tranportasi onliner yang digunakan & & $0,00 \%$ \\
\hline - $\mathrm{A}$ & 32 & $33,33 \%$ \\
\hline - B & 32 & $33,33 \%$ \\
\hline - $\mathrm{C}$ & 32 & $33,33 \%$ \\
\hline Total & 96 & $100,00 \%$ \\
\hline \multicolumn{3}{|l|}{ Usia } \\
\hline - $<25$ tahun & 45 & $46,88 \%$ \\
\hline - 26-30 tahun & 15 & $15,63 \%$ \\
\hline - 31-35 tahun & 16 & $16,67 \%$ \\
\hline - $36-40$ tahun & 6 & $6,25 \%$ \\
\hline - > $>40$ tahun & 14 & $14,58 \%$ \\
\hline Total & 96 & $100,00 \%$ \\
\hline \multicolumn{3}{|l|}{ Pekerjaan } \\
\hline - Pelajar/Mahasiswa & 33 & $34,38 \%$ \\
\hline - Karyawan/Honorer & 36 & $37,50 \%$ \\
\hline - PNS & 22 & $22,92 \%$ \\
\hline - Buruh & 1 & $1,04 \%$ \\
\hline - IRT & 4 & $4,17 \%$ \\
\hline Total & 96 & $100.00 \%$ \\
\hline
\end{tabular}

Hasil analisis deskriptif mengenai lima komponen usability testing pada transportasi online A diuraikan sebagai berikut

\begin{tabular}{lccccc}
\hline \multicolumn{1}{c}{ Komponen } & No & Min & Max & Mean & Stdev \\
\hline Kemudahan & 1 & 3 & 4 & 3,84 & 0,37 \\
& 2 & 3 & 4 & 3,88 & 0,34 \\
& 3 & 3 & 4 & 3,84 & 0,37 \\
\hline Efisiensi & 4 & 3 & 4 & 3,63 & 0,49 \\
& 5 & 3 & 4 & 3,69 & 0,47 \\
& 6 & 3 & 4 & 3,78 & 0,42 \\
\hline \multicolumn{1}{c}{ Komponen } & No & Min & Max & Mean & Stdev \\
\hline Mudah dingat & 7 & 3 & 4 & 3,75 & 0,44 \\
& 8 & 3 & 4 & 3,81 & 0,40 \\
& 9 & 3 & 4 & 3,72 & 0,46 \\
& 10 & 3 & 4 & 3,66 & 0,48 \\
\hline Kesalahan & 11 & 1 & 4 & 2,75 & 0,92 \\
& 12 & 1 & 4 & 3,22 & 0,75 \\
& 13 & 2 & 4 & 3,50 & 0,62 \\
\hline Kepuasan & 14 & 2 & 4 & 3,53 & 0,57 \\
& 15 & 1 & 4 & 3,25 & 0,80 \\
& 16 & 3 & 4 & 3,72 & 0,46 \\
\hline
\end{tabular}

Gambar 6. Usability testing transportasi A

Tingkat kepuasan pengguna aplikasi tranportasi online A memiliki nilai terendah 3,25 pada butir nomor 15 yang artinya masih ada responden yang merasa kecewa dalam penggunaan aplikasi transportasi online $\mathrm{A}$.
Hasil analisis deskriptif mengenai lima komponen usability testing pada transportasi online B diuraikan sebagai berikut

\begin{tabular}{lccccc}
\hline \multicolumn{1}{c}{ Komponen } & No & Min & Max & Mean & Stdev \\
\hline Kemudahan & 1 & 3 & 4 & 3,69 & 0,47 \\
& 2 & 3 & 4 & 3,56 & 0,50 \\
& 3 & 3 & 4 & 3,50 & 0,51 \\
\hline Efisiensi & 4 & 3 & 4 & 3,44 & 0,50 \\
& 5 & 2 & 4 & 3,44 & 0,62 \\
& 6 & 3 & 4 & 3,63 & 0,49 \\
\hline Mudah diingat & 7 & 3 & 4 & 3,56 & 0,50 \\
& 8 & 2 & 4 & 3,50 & 0,62 \\
& 9 & 2 & 4 & 3,47 & 0,67 \\
& 10 & 2 & 4 & 3,44 & 0,72 \\
\hline Kesalahan & 11 & 1 & 4 & 2,94 & 1,05 \\
& 12 & 1 & 4 & 3,19 & 0,82 \\
& 13 & 2 & 4 & 3,31 & 0,59 \\
\hline Kepuasan & 14 & 2 & 4 & 3,50 & 0,62 \\
& 15 & 2 & 4 & 3,38 & 0,71 \\
& 16 & 2 & 4 & 3,44 & 0,62 \\
\hline
\end{tabular}

Gambar 7. Usability testing transportasi B

Indikator nomor 11 memiliki nilai rata-rata terendah yaitu 2,94 aplikasi transportasi online masih ditemukan kesalahan (error) oleh pengguna, selain itu juga masih ada yang menganggap bahwa kses informasi melalui aplikasi transportasi online B tidak memiliki jaminan keamanan. Dari segi kepuasan penggunaan aplikasi transportasi online B secara keseluruhan masih ditemukan pengguna yang merasa tidak nyaman dalam melakukan order maupun transaksi,

Hasil analisis deskriptif mengenai lima komponen usability testing pada transportasi online $\mathrm{C}$ diuraikan sebagai berikut

\begin{tabular}{lccccc}
\hline \multicolumn{1}{c}{ Komponen } & No & Min & Max & Mean & Stdev \\
\hline Kemudahan & 1 & 2 & 4 & 3,031 & 0,90 \\
& 2 & 2 & 4 & 2,719 & 0,96 \\
& 3 & 3 & 4 & 3,469 & 0,51 \\
\hline Efisiensi & 4 & 2 & 4 & 3,625 & 0,55 \\
& 5 & 2 & 4 & 2,344 & 0,75 \\
& 6 & 2 & 4 & 3,344 & 0,94 \\
\hline \hline Komponen & No & Min & Max & Mean & Stdev \\
\hline Mudah diingat & 7 & 2 & 4 & 2,813 & 0,69 \\
& 8 & 3 & 4 & 3,469 & 0,51 \\
& 9 & 2 & 4 & 2,969 & 0,59 \\
& 10 & 3 & 4 & 3,469 & 0,51 \\
\hline Kesalahan & 11 & 1 & 4 & 2,188 & 0,86 \\
& 12 & 1 & 4 & 2,594 & 0,80 \\
& 13 & 2 & 4 & 2,938 & 1,01 \\
\hline Kepuasan & 14 & 2 & 4 & 2,938 & 1,01 \\
& 15 & 1 & 4 & 2,906 & 1,06 \\
& 16 & 1 & 4 & 2,281 & 0,77 \\
\hline
\end{tabular}

Gambar 8. Usability testing transportasi $C$ 
Nilai rata-rata yang kurang dari 3 terutama pada nomor 11 sebesar 2,188 hal ini menjelaskan bahwa masih banyak sekali responden yang menganggap bahwa transportasi online $\mathrm{C}$ pernah mengalami kesalahan (error).

Uji Beda Aplikasi Transportasi Online A dengan Aplikasi Transportasi Online B

Hasil uji beda dengan independent sample test diuraikan dalam gambar berikut.

\begin{tabular}{lcccc}
\hline $\begin{array}{c}\text { Komponen } \\
\text { Usability Testing }\end{array}$ & Aplikasi & $\mathrm{t}_{\text {statistik }}$ & Sig. & Keterangan \\
\hline Kemudahan & $\begin{array}{l}\text { Transportasi Online A } \\
\text { Transportasi Online B }\end{array}$ & 3,009 & 0,004 & $\begin{array}{c}\text { Terdapat } \\
\text { Perbedaan }\end{array}$ \\
\hline Efisiensi & $\begin{array}{l}\text { Transportasi Online A } \\
\text { Transportasi Online B }\end{array}$ & 1,879 & 0,065 & $\begin{array}{c}\text { Tidak Terdapat } \\
\text { Perbedaan }\end{array}$ \\
\hline Mudah diingat & $\begin{array}{l}\text { Transportasi Online A } \\
\text { Transportasi Online B }\end{array}$ & 1,956 & 0,056 & $\begin{array}{c}\text { Tidak Terdapat } \\
\text { Perbedaan }\end{array}$ \\
\hline Kesalahan & $\begin{array}{l}\text { Transportasi Online A } \\
\text { Transportasi Online B }\end{array}$ & 0,057 & 0,954 & $\begin{array}{c}\text { Tidak Terdapat } \\
\text { Perbedaan }\end{array}$ \\
\hline Kepuasan & $\begin{array}{l}\text { Transportasi Online A } \\
\text { Transportasi Online B }\end{array}$ & 0,421 & 0,675 & $\begin{array}{c}\text { Tidak Terdapat } \\
\text { Perbedaan }\end{array}$ \\
\hline
\end{tabular}

Gambar 9. Uji beda aplikasi transportasi $A-B$

2. Uji Beda Aplikasi Transportasi Online A dengan Aplikasi Transportasi Online C

Hasil uji beda dengan independent sample test diuraikan dalam gambar berikut

\begin{tabular}{|c|c|c|c|c|}
\hline $\begin{array}{c}\text { Komponen } \\
\text { Usability Testing }\end{array}$ & Aplikasi & $t_{\text {statistik }}$ & Sig. & Keterangan \\
\hline Kemudahan & $\begin{array}{l}\text { Transportasi Online A } \\
\text { Transportasi Online C }\end{array}$ & 7,673 & 0,000 & $\begin{array}{l}\text { Terdapat } \\
\text { Perbedaan }\end{array}$ \\
\hline Efisiensi & $\begin{array}{l}\text { Transportasi Online A } \\
\text { Transportasi Online C }\end{array}$ & 4,729 & 0,000 & $\begin{array}{c}\text { Terdapat } \\
\text { Perbedaan }\end{array}$ \\
\hline Mudah diingat & $\begin{array}{l}\text { Transportasi Online A } \\
\text { Transportasi Online C }\end{array}$ & 5,738 & 0,000 & $\begin{array}{c}\text { Terdapat } \\
\text { Perbedaan }\end{array}$ \\
\hline Kesalahan & $\begin{array}{l}\text { Transportasi Online A } \\
\text { Transportasi Online C }\end{array}$ & 3,244 & 0,002 & $\begin{array}{l}\text { Terdapat } \\
\text { Perbedaan }\end{array}$ \\
\hline Kepuasan & $\begin{array}{l}\text { Transportasi Online A } \\
\text { Transportasi Online C }\end{array}$ & 4,463 & 0,000 & $\begin{array}{l}\text { Terdapat } \\
\text { Perbedaan }\end{array}$ \\
\hline
\end{tabular}

Gambar 10. Uji beda aplikasi trasnportasi A - C

3. Uji Beda Aplikasi Transportasi Online B dengan Aplikasi Transportasi Online C

Hasil uji beda dengan independent sample test diuraikan dalam gambar berikut.

\begin{tabular}{|c|c|c|c|c|}
\hline $\begin{array}{c}\text { Komponen } \\
\text { Usability Testing }\end{array}$ & Aplikasi & $\mathrm{t}_{\text {statistik }}$ & Sig. & Keterangan \\
\hline Kemudahan & $\begin{array}{l}\text { Transportasi Online B } \\
\text { Transportasi Online C }\end{array}$ & 4,365 & 0,000 & $\begin{array}{l}\text { Terdapat } \\
\text { Perbedaan }\end{array}$ \\
\hline Efisiensi & $\begin{array}{l}\text { Transportasi Online B } \\
\text { Transportasi Online C }\end{array}$ & 3,022 & 0,004 & $\begin{array}{c}\text { Terdapat } \\
\text { Perbedaan }\end{array}$ \\
\hline Mudah diingat & $\begin{array}{l}\text { Transportasi Online B } \\
\text { Transportasi Online C }\end{array}$ & 2,602 & 0,012 & $\begin{array}{c}\text { Terdapat } \\
\text { Perbedaan }\end{array}$ \\
\hline Kesalahan & $\begin{array}{l}\text { Transportasi Online B } \\
\text { Transportasi Online C }\end{array}$ & 2,910 & 0,005 & $\begin{array}{c}\text { Terdapat } \\
\text { Perbedaan }\end{array}$ \\
\hline Kepuasan & $\begin{array}{l}\text { Transportasi Online B } \\
\text { Transportasi Online C }\end{array}$ & 3,919 & 0,000 & $\begin{array}{c}\text { Terdapat } \\
\text { Perbedaan }\end{array}$ \\
\hline
\end{tabular}

Gambar 11. Uji beda aplikasi transportasi B - C

Berdasarkan hasil analisis data diketahui bahwa nilai ratarata dari setiap komponen kemudian nilai rata-rata tersebut dikategorikan menurut ketentuan berikut. (1) nilai rata-rata antara 3,01 - 4,00 dikategorikan tinggi, nilai rata-rata antara 2,01 - 3,00 dikategorikan sedang, kemudian nilai rata-rata antara 1,00 - 2,00 dikategorikan rendah.

\begin{tabular}{lcccccc}
\hline $\begin{array}{c}\text { Komponen } \\
\text { Usability }\end{array}$ & \multicolumn{2}{c}{$\begin{array}{c}\text { Transportasi } \\
\text { Online A }\end{array}$} & \multicolumn{2}{c}{$\begin{array}{c}\text { Transportasi } \\
\text { Online B }\end{array}$} & \multicolumn{2}{c}{$\begin{array}{c}\text { Transportasi } \\
\text { Online B }\end{array}$} \\
\cline { 2 - 7 } Testing & Mean & Kategori & Mean & Kategori & Mean & Kategori \\
\hline Kemudahan & 3,85 & Tinggi & 3,58 & Tinggi & 3,07 & Tinggi \\
Efisiensi & 3,70 & Tinggi & 3,50 & Tinggi & 3,10 & Tinggi \\
Mudah diingat & 3,73 & Tinggi & 3,50 & Tinggi & 3,18 & Tinggi \\
Kesalahan & 3,16 & Tinggi & 3,15 & Tinggi & 2,57 & Sedang \\
Kepuasan & 3,50 & Tinggi & 3,44 & Tinggi & 2,71 & Sedang \\
\hline
\end{tabular}

Gambar12. Perbandingan nilai rata-rata

\section{KESIMPULAN}

Hasil analisis dan pembahasan yang telah diuraikan pada bagian sebelumnya dapat disimpulkan bahwa: Aplikasi transportasi online A memiliki tingkat kemudahaan, efisiensi, mudah diingat, keamanan dan kepuasan pengguna yang dapat dikategorikan tinggi dengan skor rata-rata lebih besar dari tiga.

Aplikasi transportasi online B memiliki tingkat kemudahaan, efisiensi, mudah diingat, keamanan dan kepuasan pengguna yang dapat dikategorikan tinggi dengan skor rata-rata lebih besar dari tiga.

Aplikasi transportasi online $\mathrm{C}$ memiliki tingkat kemudahan, efisiensi dan mudah diingat yang masih dapat dikategorikan tinggi dengan skor rata-rata diatas tiga, namun memiliki tingkat keamanan dan kepuasan pengguna yang sudah masuk kategori sedang.

Tidak terdapat perbedaan usability testing pada aplikasi tranportasi online A dengan transportasi online B untuk mengukur tingkat kepuasan pengguna di wilayah Jabobetabek. 
Terdapat perbedaan usability testing pada aplikasi tranportasi online A dengan transportasi online C secara singnifikan untuk mengukur tingkat kepuasan pengguna di wilayah Jabobetabek.

Terdapat perbedaan usability testing pada aplikasi tranportasi online B dengan transportasi online C secara singnifikan untuk mengukur tingkat kepuasan pengguna di wilayah Jabobetabek

\section{REFERENSI}

[1] Ghozali, I. (2016). Aplikasi Analisis Multivariete Dengan Program IBM SPSS 23. Semarang: BPFE.

[2] Noor, J. (2014). Analisis Data Penelitian Ekonomi dan Manajemen. Jakarta: Grasindo.

[3] Sugiyono. (2017). Metode Penelitian kuantitatif. Kualitatif dan R\&D. Bandung: Alfabeta.

[4] Sukmadinata, N. S. (2013). Metode Penelitian Pendidikan. Bandung : Remaja Rosdakarya Offset.

[5] Alfiqie, M. Y., Aknuranda, I., \& Wardani, N. H. (2008) Evaluasi Usability Pada Aplikasi UBER Menggunakan Pengujian Usability. Jurnal Pengembangan Teknologi Informasi dan Ilmu Komputer, 2(9), 2599-2606.

[6] Aries, T. M., Ranius, Y. A., \& Saputri, N. A. (2017) Usability Testing Untuk Mengukur Penggunaan Website STIK Bina Husada Palembang. Jurnal Teknik Informatika, Universitas Bina Darma Palembang, 1-12.

[7] Azizah, A., \& Adawia, P. R. (2018). Analisis Perkembangan Industri Transportasi Online di Era Inovasi Disruptif (Studi Kasus PT Gojek Indonesia). Cakrawala-Jurnal Humaniora, 18(2), 149-156.

[8] Farouqi, M. I., Aknuranda, I., \& Herlambang, A. D. (2018). Evaluasi Usability pada Aplikasi Go-Jek Dengan Menggunakan Metode Pengujian Usability. Jurnal Pengembangan Teknologi Informasi dan Ilmu Komputer, 2(9), 3110-3117.

[9] Permana, N. R., Aknuranda, I., \& Rokhmawati, R. I. (2018). Evaluasi Usability pada Aplikasi Grab dengan Menggunakan Metode Pengujian Usability. Jurnal Pengembangan Teknologi Informasi dan Ilmu Komputer, 2(10), 150-3156.

[10] Priambodo, R. G., Wijoyo, S. H., \& Indah, R. (2019). Evaluasi Aplikasi Anterin Menggunakan Metode
Pengujian Usability. Jurnal Pengembangan Teknologi Informasi dan Ilmu Komputer, 3(6), 5987-5993.

[11] Rahayu, I. P. (2018). Transportasi Online dalam Pandangan Pembangunan Berkelanjutan (SDGs) dan Dampak Ekologi yang Ditimbulkan. Jurnal Universitas Muhammadiyah Yogyakarta.

[12] Sekaran, U., \& Bougie, R. (2016). Reseach Methods for Business: A Skill Building Approach. United Kingdom: John Willey \& Sons.

[13] Lemeshow, S., Hosmer, D. W., Klar, J., \& Lwanga, S. K. (1997). Besar Sampel dalam Penelitian Kesehatan. Yogyakarta: Gajah Mada University Press.

[14] Nielsen Norman Group. (2014, Januari 12). Turn User Goals into Task Scenarios for Usability Testing. Retrieved from Nielsen Norman Group: https://www.nngroup.com/articles/task-scenariosusability-testing/ 